\title{
The Effect of Methanotrophic Bacteria Application on Paddy Growth and Methane Emission in Rainfed Rice of Kupang Regency, East Nusa Tenggara, Indonesia
}

\author{
Rizki Adiputra Taopan ${ }^{1}$, Iman Rusmana², Dwi Andreas Santosa ${ }^{3}$ \\ ${ }^{1}$ Graduate School, Department of Soil Science and Land Resource, Bogor Agricultural University, INDONESIA \\ Email: rizkimic ro@g mail.com \\ ${ }^{2}$ Department of Biology, Bogor Agricultural University, INDONESIA \\ Email: irusmana@ipb.ac.id \\ ${ }^{3}$ Department of Soil Science and Land Resource, Bogor Agricultural University, INDONESIA \\ Email: dsantosa@indo.net.id
}

\begin{abstract}
Rice productivity in province of East Nusa Tenggara (ENT) is low due to the soil condition. One of the rice-producing regency in ENT is Kupang Regency with rainfed rice type. Paddy fields have also become a major source of methane emissions $\left(\mathrm{CH}_{4}\right)$ as one of important greenhouse gases. This research aims to know the effect of methanotrophic bacteria application on paddy growth and methane emission at rainfed rice. Bacteria that used is Methylocystisrosea BGM 1, Methylobacter sp. SKM 14, Methylocystispalvus BGM 3 and Methylococcuscapsulatus BGM 9. This research used completely random design with threatment: (1) NPK 100\% (P1), (2) NPK 50\% (P2),(3) withoutfertilizer (P3), (4) NPK 100\% + methanotrophic (P4), NPK 50\% + methanotrophic (P5), and methanotrophic bacteria (P6). Gas sampling using closed chamber method.The application ofmethanotrophic bacteria increased the rice production. Treatment NPK 50\% + methanotrophic (P5) from that rice field produced $7.0 \mathrm{tha^{-1 }}$ dry grain weight and methanotrophic bacteria treatment without NPK (P6) with improved $6.6 \mathrm{t} h \mathrm{a}^{-1}$ dry grain weight, higher than controls of $4.9 \mathrm{ha}^{-1}$ dry grain weight without any addition of synthetic fertilizer.The inoculation of methanotrophic

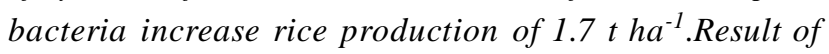
methane flux measurement showed that application of methanotrophic bacteria may decrease methane emission in treatment of $100 \% N P K+$ methanotrophic (P4) $(30$ $D A P)$ and treatment of $50 \% \mathrm{NPK}+$ methanotrophic (P5) (60 DAP), -6.27 $\mathrm{mg} / \mathrm{m}^{2} / \mathrm{d}$ and $-23.87 \mathrm{mg} / \mathrm{m}^{2} / \mathrm{d}$, respectively.
\end{abstract}

Keywords-Kupang regency, Methane emission, Methanotrophic, Rainfed rice.

\section{INTRODUCTION}

Rice is a basic requirement of Indonesian society, including the province of East Nusa Tenggara (ENT).
Rice productivity in ENT belongs low because the soil is less fertile and arid climate with rainfall between 201-300 $\mathrm{mm}$ (BMKG 2017). One of the rice-producing regency in ENT is Kupang Regency. In the year 2013 produced rice as much as $60.469 \mathrm{t}, 13.846$ ha of which is rainfed rice (BPS 2013). Farmers in the Regency of Kupang still using synthetic fertilizers to increase crop production. Practices will further lower soil fertility due to damage to physical, chemical, and biological soil condition (Havlinet al. 2005). In addition, the use of inorganic fertilizers also has an impact on global warming.

Wetlands such as paddy fields have also become a major source of methane emissions $\left(\mathrm{CH}_{4}\right)$ as greenhouse gases. The activity of methanogenesis by methanogen bacteria on paddy fields produce $\mathrm{CH}_{4}$ gas (Le Mer and Roger, 2001). The global warming potential of methane gas is 25 times greater than $\mathrm{CO}_{2}$ (IPCC, 2007). According to Conrad and Rothfus (1991), as much as $80 \%$ of methane gas in the rice fields can be oxidized by the methanotrophic bacteria. This can be a solution in mitigating the emission of methane gas in the paddy fields.

Some of the methanotrophic bacteria has been succesfully isolated from paddy fields in Sukabumi and Bogor (Hapsari, 2008). Isolates Methylocystisrosea BGM 1 and Methylobacter sp. SKM 14 are known to have pmoAgene whereas isolates BGM 9 have the mmoXgene (Rusmana and Akhdiya, 2009). Isolates MethylocystispalvusBGM 3 and MethylococcuscapsulatusBGM 9 known to have nifH and nifD genes these play a role in the nitrogen fixation (Bintartiet al. 2014). Methanotrophic bacteria have been tested on organic and inorganic paddy fields. The trial reduced methane gas to $20.47 \%$ when compared with the control and improved the vegetative phase of rice growth (Pingak et al. 2014; Sutantoet al. 2014). Trials have also been conducted on paddy fields in the lowlands. The trial 
reduced of methane gas and increased the growth of vegetative phase on rice and the generative phase (Sukmawatiet al. 2015). This research aims to know thepaddy growthand methane emissions in the application of methanotrophic bacteria at therainfed rice.

\section{METHODS}

\subsection{Culturing Bacterial Is olates}

Methanotrophic bacteria isolates i.e. BGM 1, 3, 9, and SKM 14 were cultured in NMS (Nitrate Mineral Salt) plus $1 \%$ methanol $(\mathrm{v} / \mathrm{v})$, incubated at room temperature $\left( \pm 28^{\circ} \mathrm{C}\right)$ for $7-10$ days and shakedup to reach $10^{8} \mathrm{CFU}$ cell $/ \mathrm{mL}$.

\subsection{Seedling and Plantation}

Seeds of paddy variety Ciherang were germinated for $48 \mathrm{~h}$. After that, the seed was sowed in the field for 20 days to make seedling. Before transplanting, the seedling was dipped in a mixture of methanotrophic bacteriafor 15-20 minutes, then plantated with a distance of $20 \times 20 \mathrm{~cm}$ which 3 seedling in every hole. Five plants selected from every plot of treatment for measurement of growth parameters.

\subsection{Experimental Design}

The experimental design used was completly random design with one factor i.e. fertilization. The treatment consists of: (1) NPK100\% (P1), (2) NPK 50\% (P2), (3) without fertilizer (P3), (4) NPK $100 \%+$ methanotrophic (P4), NPK 50\% + methanotrophic (P5), and methanotrophic bacteria (P6). Each treatment has 4 replications.

\subsection{Measurement of Growth Parameters}

Paddy growth was observed at 30, 60, and 90 day after plant(DAP). During the vegetative growth plant height and number of tillers was measurement. The shoot dry weight, number of panicles per plants, grains per panicle, empty grain, weight 1000 grain, and the dry grain weight was measured of the harvest.

2.5 Gas Sampling and Measurement Methane Fluxes Gas sampling was using closed chamber method. Gas sampling is done at 30,60, and 90 day after plant DAPwith time taking between 06.00-11.00 am. Gas sampling was done every 10 minutes from 0 to 30 minutes. Methane fluxes were calculated as follows by IAEA (1993) :

$E=\frac{\mathrm{dc}}{\mathrm{dt}} \times \frac{\mathrm{Vch}}{\mathrm{Ach}} \times \frac{\mathrm{mW}}{\mathrm{mV}} \times \frac{273,2}{(273,2+\mathrm{T})}$

$$
\begin{array}{ll}
\mathrm{E} & =\mathrm{CH}_{4} \text { emission rate }\left(\mathrm{mg} / \mathrm{m}^{2} / \mathrm{d}\right) \\
\mathrm{dc} & =\text { Difference concentration }(\mathrm{ppm}) \\
\mathrm{dt} & =\text { Time interval }(\mathrm{min}) \\
\mathrm{Vch} & =\text { Volume of the chamber }\left(\mathrm{m}^{3}\right) \\
\mathrm{Ach} & =\text { Basal area of the chamber }\left(\mathrm{m}^{2}\right)
\end{array}
$$

$$
\begin{array}{ll}
\mathrm{mW} & =\text { Molecular weight } \\
\mathrm{mV} & =\text { Molecular volume } \\
\mathrm{T} & =\text { Temperature }\left({ }^{\circ} \mathrm{C}\right)
\end{array}
$$

\subsection{Data Analysis}

Data was analysed using microsoftexel software and software SAS 9 portable at the confidence level of $95 \%$. The data showed a significant difference, was tested with Duncan multiple range test (DMRT).

\section{RESULTS}

\subsection{Paddy Growth and Production}

Observation of plant height and number of tillers were at 30, 60, and 90 DAP (Table 1 and Table 2). The observations showed that the treatment combination of NPK with methanotrophic bacteria was not significantly different from the treatment without combinations, but all treatment was significantly different with control without fertilization (P3). Treatment of NPK $100 \%+$ methanotrophic (P4) and treatment of methanotrophic bacteria (P6) without fertilizer higher showed plant height than other treatments at 30 DAP. Treatment NPK 100\% + methanotrophic (P4) showed the highest plants height on 90 DAP than other treatment, while treatment of methanotrophic bacteria (P6) showed the lowest plant height.

Observation of the number of tillers showed that the treatment combination of NPK with methanotrophicbacteria was not significantly different with the treatment without the combination at 30 and $60 \mathrm{DAP}$, but all treatment was significantly different with the treatment without fertilization (P3). Treatment NPK 50\% + methanotrophic (P5) was not significantly different with the control treatment without fertilization (P3) on 90 DAP. Treatment of methanotrophic bacteria (P6) was significantly different with the control treatment without fertilization at 60 and 90 DAP.

Table.1: Plant height at 30, 60, 90 DAP. (P1. NPK 100\%; P2. NPK 50\%; P3. Without Fertilization; P4.

Methanotrophic + NPK 100\%; P5. Methanotrophic + NPK 50\%; P6. Methanotrophic)

\begin{tabular}{cccc}
\hline \multirow{2}{*}{ Treatment } & \multicolumn{3}{c}{ Plant Height (cm)*) } \\
\cline { 2 - 4 } & 30 DAP & 60 DAP & 90 DAP \\
\hline P1 & $49.35 \mathrm{ab}$ & $89.40 \mathrm{a}$ & $88.40 \mathrm{a}$ \\
P2 & $49.30 \mathrm{ab}$ & $85.90 \mathrm{a}$ & $90.00 \mathrm{a}$ \\
P3 & $45.70 \mathrm{~b}$ & $80.70 \mathrm{~b}$ & $81.85 \mathrm{bc}$ \\
P4 & $50.90 \mathrm{a}$ & $87.50 \mathrm{a}$ & $90.60 \mathrm{a}$ \\
P5 & $48.15 \mathrm{ab}$ & $89.25 \mathrm{a}$ & $85.65 \mathrm{ab}$ \\
P6 & $50.70 \mathrm{a}$ & $81.15 \mathrm{~b}$ & $79.10 \mathrm{c}$ \\
\hline
\end{tabular}


*) Numbers within a column followed by the same letter are not significantly different at $5 \%$ level by DMRT $(\alpha=$ 0.05

Table.2: Number of tillers at 30, 60, 90 DAP. (P1. NPK 100\%; P2. NPK 50\%; P3. Without Fertilization; P4. Methanotrophic + NPK 100\%; P5. Methanotrophic + NPK 50\%; P6. Methanotrophic)

\begin{tabular}{cccc}
\hline \multirow{2}{*}{ Treatment } & \multicolumn{3}{c}{ Number of Tillers*) } \\
\cline { 2 - 4 } & 30 DAP & 60 DAP & 90 DAP \\
\hline P1 & $31.25 \mathrm{a}$ & $29.75 \mathrm{a}$ & $27.60 \mathrm{a}$ \\
P2 & $27.05 \mathrm{ab}$ & $26.00 \mathrm{ab}$ & $26.50 \mathrm{ab}$ \\
P3 & $22.00 \mathrm{~b}$ & $23.20 \mathrm{~b}$ & $21.00 \mathrm{~b}$ \\
P4 & $32.30 \mathrm{a}$ & $24.80 \mathrm{ab}$ & $25.35 \mathrm{ab}$ \\
P5 & $28.05 \mathrm{a}$ & $24.15 \mathrm{ab}$ & $21.65 \mathrm{~b}$ \\
P6 & $28.35 \mathrm{a}$ & $14.60 \mathrm{c}$ & $14.95 \mathrm{c}$ \\
\hline
\end{tabular}

*) Numbers within a column followed by the same letter are not significantly different at $5 \%$ level by DMRT $(\alpha=$ 0.05

Harvest parameters observation showedin Table 3 . Observation of shoot dry weight showed the treatment combination of NPK with the methanotrophic bacteria was not significantly different with the treatment without the combination, while the treatment NPK 50\% + methanotrophic(P5) and treatment of methanotrophicbacteria (P6) was not significantly different with control without NPK (P3). Average shoot dry grain weight of P5 and P6 treatment was higher than treatment of P3.Treatment of $100 \%$ NPK (P1)produced the highest number of panicles per plants, while treatment of methanotrophic bacteria (P6) produced the lowest panicles per plants. Treatment of NPK $50 \%(\mathrm{P} 2)$ and treatment of NPK $100 \%$ + methanotrophic (P4) was not significantly different with treatment of $100 \%$ NPK (P1), whereas treatment of NPK $50 \%$ + methanotrophic (P5) was not significantly different with the treatment of $50 \%$ NPK (P2), control without NPK (P3), and treatment of NPK $100 \%$ + methanotrophic (P4).

All the treatments were not significantly different in the number of grains per panicle parameter. But treatment combination of NPK with methanotrophic bacteria produced the number of grains per panicle higher than treatment without the combination. Treatment of NPK $50 \%+$ methanotrophic (P5) produced the highest number of panicles, followed by treatment of methanotrophic bacteria (P6) and treatment of NPK 100\% + methanotrophic $(\mathrm{P} 4)$. Although it produced the highest number of grains per panicle, treatment NPK $50 \%+$ methanotrophic(P5) has highest empty grain, while treatment of methanotrophic bacteria (P6) produced the lowest empty grain. Weight 1000 grain measurements were not significantly different in all treatments.

Treatment of NPK 50\% + methanotrophic (P5) produced highest dry grain weight, followed by treatment of $100 \%$ NPK (P1) and treatment of NPK $100 \%+$ methanotrophic(P4). Treatment of methanotrophic bacteria (P6) produced dry grain weighthigher than the control without NPK (P3).

Table.3: Measurement of harvest parameters (P1. NPK

100\%; P2. NPK 50\%; P3. Without Fertilization; P4.

Methanotrophic + NPK 100\%; P5. Methanotrophic + NPK 50\%; P6. Methanotrophic)

\begin{tabular}{cccccc}
\hline & $\begin{array}{c}\text { Shoot } \\
\text { Dry } \\
\text { Treatment } \\
\text { Weight } \\
(\mathrm{g})\end{array}$ & $\begin{array}{c}\text { No. of } \\
\text { Panicles } \\
\text { per } \\
\text { Plants }\end{array}$ & $\begin{array}{c}\text { Grains } \\
\text { per } \\
\text { Panicle }\end{array}$ & $\begin{array}{c}\text { Empty } \\
\text { Grain }\end{array}$ & $\begin{array}{c}\text { Weight } \\
1000 \\
\text { Grain } \\
(\mathrm{g})\end{array}$ \\
\hline P1 & $114.03 \mathrm{a}$ & $27.16 \mathrm{a}$ & $97.94 \mathrm{a}$ & $20.00 \mathrm{ab}$ & $18.75 \mathrm{a}$ \\
P2 & $118.83 \mathrm{a}$ & $23.55 \mathrm{ab}$ & $98.11 \mathrm{a}$ & $21.49 \mathrm{ab}$ & $20.25 \mathrm{a}$ \\
P3 & $64.43 \mathrm{~b}$ & $19.16 \mathrm{~b}$ & $99.27 \mathrm{a}$ & $13.08 \mathrm{~b}$ & $20.00 \mathrm{a}$ \\
P4 & $115.33 \mathrm{a}$ & $24.33 \mathrm{ab}$ & $99.47 \mathrm{a}$ & $18.16 \mathrm{ab}$ & $20.25 \mathrm{a}$ \\
P5 & $95.25 \mathrm{ab}$ & $20.74 \mathrm{~b}$ & $109.80 \mathrm{a}$ & $24.46 \mathrm{a}$ & $20.00 \mathrm{a}$ \\
P6 & $97.57 \mathrm{ab}$ & $13.93 \mathrm{c}$ & $108.80 \mathrm{a}$ & $12.63 \mathrm{~b}$ & $20.50 \mathrm{a}$ \\
\hline
\end{tabular}

Table.4: Dry grain weight parameters (P1. NPK 100\%; P2. NPK 50\%; P3. Without Fertilization; P4.

Methanotrophic + NPK 100\%; P5. Methanotrophic + NPK 50\%; P6. Methanotrophic)

\begin{tabular}{cc} 
Treatment & $\begin{array}{c}\text { Dry Grain } \\
\text { Weight }\left(\mathrm{t} \mathrm{ha}^{-1}\right)\end{array}$ \\
\hline P1 & $6.8 \mathrm{ab}$ \\
P2 & $5.6 \mathrm{bc}$ \\
P3 & $4.9 \mathrm{c}$ \\
P4 & $6.7 \mathrm{ab}$ \\
P5 & $7.0 \mathrm{a}$ \\
P6 & $6.6 \mathrm{ab}$ \\
\hline
\end{tabular}

*)Numbers within a column followed by the same letter are not significantly different at $5 \%$ level by DMRT $(\alpha=$ 0.05

\subsection{Methane Flux}

The highest methane flux was shown in 30 DAP. Treatment of NPK without inoculation of methanotrophic bacteria showed highest emissions. Treatment of $50 \%$ NPK (P2) emmited $60.69 \mathrm{CH}_{4} \mathrm{mg} / \mathrm{m}^{2} / \mathrm{d}$, followed by treatment NPK $100 \%$ (P1) of $54.72 \mathrm{mg} / \mathrm{m}^{2} / \mathrm{d}$. Treatment of NPK with bacterial inoculation of P5 (NPK50\% +methanotrophic) emitted $61.60 \quad \mathrm{CH}_{4} \mathrm{mg} / \mathrm{m}^{2} / \mathrm{d}$ and treatment of methanotrophic bacterial alone without fertilizer (P6) produced $18.97 \mathrm{CH}_{4} \mathrm{mg} / \mathrm{m}^{2} / \mathrm{d}$.

Significant methane absorption (sink) was showed in the treatment of NPK100\% + methanotrophic (P4) and 
emmited $-6.27 \mathrm{mg} / \mathrm{m}^{2} / \mathrm{d}$ at $30 \mathrm{DAP}$, treatment of $50 \%$ NPK (P2) of $-10.72 \mathrm{mg} / \mathrm{m}^{2} / \mathrm{d}$ at 60 DAP, and treatment of NPK $50 \%+$ methanotrophic (P5) of $-23.87 \mathrm{mg} / \mathrm{m}^{2} / \mathrm{d}$ at 60 DAP. All the treatments showed a low methane flux on 90 DAP. This because of low rainfall so there was no formation of anaerobic environment as a habitat of methanogenic bacteria that produce methane gas.

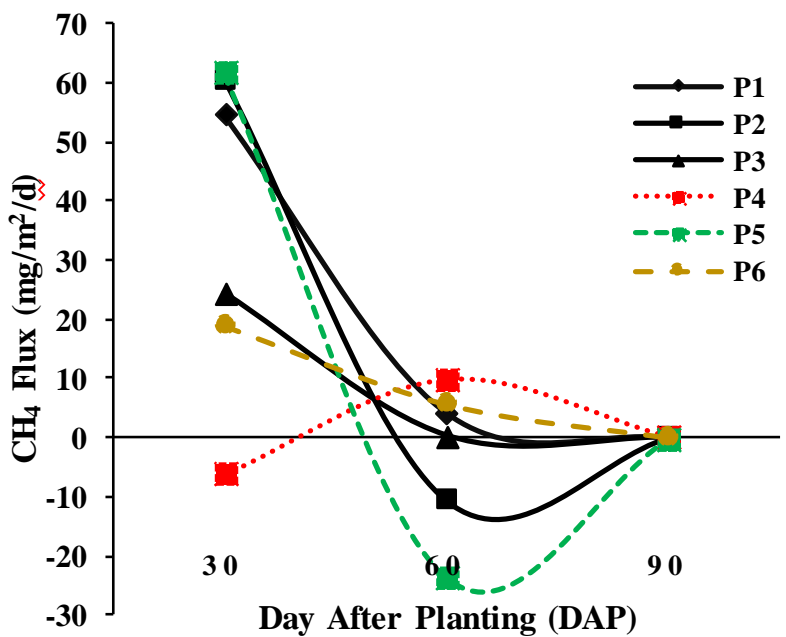

Fig.1: $\mathrm{CH}_{4}$ Flux at 30, 60, 90 DAP. (P1. NPK 100\%; P2. NPK 50\%; P3. Without Fertilization; P4. NPK $100 \%+$ Methanotrophic; P5. NPK 50\% + Methanotrophic; P6.

\section{Methanotrophic)}

\section{DISCUSSION}

Generally, the combination of methanotrophic bacteria and NPK have no effect in stimulating the growth of paddy in the vegetative phase, based on plant height parameters (Table 1) and the number of tillers (Table 2). According to Suparthaet al. (2012) treatment of solid organic fertilizers and organic liquid fertilizer has no effect against paddy height. Plant height and numbers of tillers has decreased at each observation. This is because of the low fertility of the soil. According to Lamberset al. (2008) plant height and the formation of tillers is an indicator of growth as a result of the interaction of the processes of photosynthesis, respiration, and nutrient transport.

Observations on harvest parameters generally do not indicate a difference between the treatment and control treatment. The results obtained in contrast to previous research by Sukmawatiet al. (2015) and Hadiantaet al. (2014). Both of these studies showed the application of methanotrophicbacteria effective in improving crop parameter. This is because of the content of soil chemical imbalance on every patch of the experiment. According to Zeigler and Puckridge (1995), the soil chemical imbalance to be another major constraint to the productivity of rainfed lowland rice. Most rainfed lowlands, particularly in Southeast Asia, have soils with potentially major fertility constraints. They list the main soil problems to be salinity, alkalinity, Fe toxicity, $\mathrm{P}$ deficiency, $\mathrm{Zn}$ deficiency, and organic and acid sulfate conditions

There are differences in the parameters of dry grain weight. Treatment of NPK $50 \%+$ methanotrophic (P5) can produce $7.0 \mathrm{t} \mathrm{ha}^{-1}$, whereas the methanotrophic bacteria treatment without NPK (P6) produces $6.6 \mathrm{t} \mathrm{ha}^{-1}$. This indicates that the application of methanotrophic bacteria effective in increasing production in rainfed rice. Methanotrophic bacteria which applicated is a consortium of several isolates (Hapsari, 2008) i.e. Methylocystisrosea BGM 1,Methylobacter sp. SKM 14, Methylocystispalvus BGM 3 and Methylococcuscapsulatus BGM 9. Isolates Methylocystispalvus and Methylobacter sp. known to have nifH and nifDgenes, the role gene in nitrogen fixation (Bintartiet al. 2014). This makes those methanotrophic bacteria can increase the availability of nitrogen for paddy growth. Nitrogen acts as a constituent of chlorophyll which is involved in the process of photosynthesis thus can increase the amount of productive grain, increase the percentage of protein and was instrumental in the preparation of the essential components of plant organs (Chaturvedi, 2005; Nettoet al. 2005; Watanabe and Kitagawa, 2000).

The Intergorvenmental Panel on Climate Change (IPCC) guidelines for compiling national inventories of greenhouse gas emissions (IPCC, 1997) distinguish between rice fields that are (1) permanently flooded and (2) those with unstable flooding regime. Rainfed rice belongs to the latter category (Wassmannet al. 2000). According to Phillips et al. (2009), one of the key factors that affect the production and consumption of methane is fertilization. Input of NPK emmited methane gas emissions range between $54.72-61.60 \mathrm{CH}_{4} \mathrm{mg} / \mathrm{m}^{2} / \mathrm{d}$ at 30 DAP, higher than control without NPK ranging from 18.97-24.44 $\mathrm{CH}_{4} \mathrm{mg} / \mathrm{m}^{2} / \mathrm{d}$. Setyantoet al. (2000) report the range of methane emissions in rainfed rice between $19-123 \mathrm{mg} / \mathrm{m}^{2} / \mathrm{d}$. The highest methane emissions occur at the beginning of the growth period and the decline in reproductive phase and the maturation phase. The intensity of the rain on the vegetative phase of $371 \mathrm{~mm}$ and declined on the reproductive phase and maturation phase, 10 and $11 \mathrm{~mm}$, respectively. Rainfall is higher in the early growth period in rainfed rice trigger high methane emissions (Wassmannet al. 2000). Methane formed by the anaerobic conditions was temporary stay stuck on flooding condition. When drying, most methane is trapped will be oxidized, however, most will escape into the atmosphere as soon as flooding recedes and macro pores aerated (Neueet al. 1995).Strong rainfall triggered high emissions in the rainfed plots while relatively dry periods resulted in lower emission rates (Setyantoet al.2000). This causes the emission of methane 
gas was low in the maturation phase from 0.0072--0.15 $\mathrm{mg} / \mathrm{m}^{2} / \mathrm{d}$.

The use of methane (sink) showed in the treatment of NPK $100 \%+$ methanotrophic (P4) at 30 DAP of -6.27 $\mathrm{mg} / \mathrm{m}^{2} / \mathrm{d}$ and treatment of NPK $50 \%+$ methanotrophic (P5) at 60 DAP of $-23.87 \mathrm{mg} / \mathrm{m}^{2} / \mathrm{d}$. Methanotrophic bacteria including obligate aerobic bacteria that can use methane as a source of carbon and energy for growth (Roslev and King, 1994). According to Dubey (2005), methanotrophic bacteria is the only biological system which acts as a reservoir of methane. Methanotrophic bacteria capable of transforming $\mathrm{CO}_{2}$ into methane oxidation process by using the enzyme methane monooxygenase (MMO). Methane oxidation can occur in the microenvironment aerobic condition on rooting zone and toxic part in the surface layer of the soil (Semrauet al. 2010).

Synthetic fertilizer can increase methane emission. Based on the observation, methane flux was increased in treatment with addition of synthetic at 30 DAP. Treatment of methanotrophic bacteria without NPK (P6) produced the lowest methane flux in 30 DAP (18.97 $\mathrm{mg} / \mathrm{m}^{2} / \mathrm{d}$ ), followed by control without fertilization (P3) $\left(24.44 \mathrm{mg} / \mathrm{m}^{2} / \mathrm{d}\right)$. Inorganic fertilizer enhanced soil porosity by increasing regular and irregular pores and caused a priming effect of native soil organic matter (Tiquiaet al. 2002) ultimately affecting $\mathrm{CH}_{4}$ and $\mathrm{N}_{2} \mathrm{O}$ emissions (Ge et al. 2010).

\section{CONCLUSION}

The application of methanotrophic bacteria (Methylocystisrosea BGM 1, Methylobacter sp. SKM 14, Methylocystispalvus BGM 3, Methylococcuscapsulatus BGM 9) increased the rice production in rainfed rice. Treatment NPK 50\% + methanotrophic (P5) from that rice field produced $7.0 \mathrm{t} \mathrm{ha}^{-1}$ dry grain weight and methanotrophic bacteria treatment without NPK (P6) with improved $6.6 \mathrm{t} \mathrm{ha}^{-1}$ dry grain weight, higher than controls of $4.9 \mathrm{ha}^{-1}$ dry grain weight without any addition of synthetic fertilizer.The application of methanotrophic bacteria may decrease methane gas emissions at rainfed rice. Treatment $100 \% \mathrm{NPK}+$ methanotrophic (P4) emmited $-6.27 \mathrm{mg} / \mathrm{m}^{2} / \mathrm{d}$ at $30 \mathrm{DAP}$ and NPK treatment $50 \%+$ methanotrophic (P5) emmited $-23.87 \mathrm{mg} / \mathrm{m}^{2} / \mathrm{d}$ at 60 DAP.

\section{REFERENCES}

[1] Bintarti AF, Rusmana I, Wahyudi AT. 2014. Identification of nifD and nifH of Methanotrophic Bacteria from Rice Field. Ann Bog. 2(18): 13-25

[2] [BMKG] BadanMeteorologiKlimatologidan Geofisika.2017. BuletinKlimatologi. Nusa Tenggara Timur (ID):

BadanMeteorologiKlimatologidanGeofisika
[3] [BPS] BadanPusatStatistik. 2013. StatistikKabupatenKupang. KabupatenKupang (ID): BadanPusatStatistik

[4] Chaturvedi I. 2005. Effect of nitrogen fertilizer on growth yield and quality of hybrid rice (Oryza sativa L.). J Eur Agric. 6(4): 611-618

[5] Conrad R andRothfuss F. 1991. Methane oxidation in the soil surface layer of a flooded rice field and the effect of ammonium. BiolFertil Soils. 12:28-32

[6] Dubey SK. 2005. Microbial ecology of methane emission in rice agroecosystem: a review. ApplEcol Environ Res. 3(2): 1-27

[7] Ge G, Li Z, Fan F, Chu G, Hou Z, Liang Y. 2010. Soil biological activity and their seasonal variations in response to long-term application of organic and inorganic fertilizers. Plant Soil. 326: 31-44

[8] Hadianta R, Rusmana I, and Mubarik NR. 2014. Diversity of nitrogen fixing bacteria based on nifH gene in rice field. AdvEnv Bio. 8(14): 63-69

[9] [IAEA] International Atomic Energy Agency. 1993. Manual on Measurement ofMethane and Nitrous Oxide Emission from Agriculture. Vienna (AUT):IAEA

[10] [IPCC] Intergovernmental Panel on Climate Change. 1997. Guidelines for National Greenhouse Gas Inventories. Cambridge University $\mathrm{Pr}$

[11] [IPCC] Intergovernmental Panel on Climate Change. 2007. Mitigation of climate change. Cambridge University Pr. Cambridge, G. B. pp. 863-998

[12] Hapsari W. 2008. Is olation and characterization of methanotropic bacteria form paddy fields in Bogor and Sukabumi (in Indonesia). Undergraduate Thesis, Biology Departement, Bogor Agricultural University, Indonesia. pp. 3-6

[13] Lambers H, Chapin FS, Pons TL. Plant Physiological Ecology 2nd edition. Springer. ISBN-10: 0387783407

[14] Le Mer I, Roger P. 2001. Production, Oxidation, Emmission and Consumption of Global Methane by Soils: a Review. Soil Biol. 37:25-50

[15] Netto AT, Campostrini E, Oliveira JG, Smith REB. 2005. Photosynthetic pigments, nitrogen, cholorophyll a fluorescence and SPAD-502 readings in coffee leaves. Hort Sci. 104(10): 199-209

[16] Neue HU, Wassmann R, Lantin RS, Alberto CR, Aduna JB, Javellana AM. 1995. Factors Affecting Methane Emission FromRice Fields. AtmosfEnv. 30: 1751-1754

[17] Phillips RL, Tanaka DL, Archer, DW, Hanson JD. 2009. Fertilizer application timing influences greenhouse gas fluxes over a growing season. $J$ Environ Qual. 38: 1569-1579

[18] Pingak GMF, Sutanto H, Akhdiya A, and Rusmana I. 2014. Effectivity of methanotrophic bacteria and Ochrobactrumanthropi as biofertilizer and emission reducer of $\mathrm{CH}_{4}$ and $\mathrm{N}_{2} \mathrm{O}$ in inorganic paddy fields. $J$ of Med and Bioeng. 3(3): 217-221 
[19] Roslev P and King GM. 1994. Survival and recovery of methanotrophic bacteria starved under oxic and anoxic conditions. Appl Environ Microbiol. 60: 26022608

[20] Rusmana I, Akhdiya A. 2009. Isolation and Characterization of Methanotrophic bacteria from rice field. Biotropia. 16(2):71-78

[21] Sukmawati D, Rusmana I, Mubarik NR. 2015. The Effectiveness of Methanotrophic Bacteria and Ochrobactrumanthropi to Reduce $\mathrm{CH}_{4}$ and $\mathrm{N}_{2} \mathrm{O}$ Emission and to Promote Paddy Growth in Lowland Paddy Fields. Mal J of Microbiol. 12(1): 50-55

[22] Semrau JD, Dispirito AA, Yoon S. 2010. Methanotrophics and copper: a review.FEMS Microbiol. 34(10): 496-531

[23] Setyanto P, Makarim AK, Fagi AM, Wassmann R andBuendia LV. 2000. Crop management affecting methane emissions from irrigated and rainfed rice in Central Java (Indonesia). Nutr Cycling Agroecosyst. 58: 85-93

[24] Supartha IN, Wijana G, Adnyana MG. 2012. Application type of organic fertilizer on organic rice farming system. E J Trop Agroeco. 1(2): 98-106.

[25] Tiquia SM, Lloyd J, Herms DA, Hoitink HAJ, Michel Jr, FC. 2002. Effects of mulching and fertilization on soil nutrients, microbial activity and rhizosphere bacterial community structure determined by analysis of TRFLPs of PCR-amplified 16S rRNA genes. Appl Soil Ecol. 21: 31-48

[26] Wassmann R, Buendia LV, Lantin RS, Bueno CS, Lubigan LA, Umali A, Nocon NN, Javellana AM \&Neue HU. 2000. Mechanisms of crop management impact onmethane emissions from rice fields in Los Baños, Philippines. Nutr Cycling Agroecosyst.58: 107-119

[27] Watanabe T, Kitagawa H. 2000. Photosynthesis and translocation of assimilates in rice plants following phloem feeding by the plant hopper Nilaparvatalugens. J Econ Entomol. 93(4): 11921198

[28] Zeigler RS, Puckridge DW. 1995. Improving sustainable productivity in rice-based rainfed lowland systems of South and Southeast Asia. Feeding 4 billion people. The challenge for rice research in the 21st century. Geo J. 35: 307-324 